\title{
ARTICLE
}

\section{Seasonal fluctuation of photosynthetic pigments of most common red seaweeds species collected from Abu Qir, Alexandria, Egypt}

Fluctuaciones estacionales de los pigmentos fotosintéticos de las algas rojas más comunes de Abu Qir, Alejandría, Egipto

\author{
Mona M. Ismail ${ }^{*}$ and Mohamed E. H. Osman²
}

\begin{abstract}
'Marine Environmental Division, National Institute of Oceanography and Fisheries, 21556 Alexandria, Egypt. "mona_es5 @yahoo.com ${ }^{2}$ Botany Department, Faculty of Science, Tanta University, Tanta 31527, Egypt. mohamed.osman@ science.tanta.edu.eg

Resumen.- Se investigaron los cambios estacionales en la composición de pigmentos [Clorofila a ( $\mathrm{Cl}$-a), carotenoides totales (Car.), ficobiliproteínas (ficoeritrina (PE), ficocianina (PC), aloficocianina (APC))], en 5 especies de Rhodophyta. Los niveles de clorofila a, carotenoides y ficobiliproteínas presentaron altos contenidos durante invierno, y disminuyeron en verano, mostrando decoloración de tejidos de rojo a verde o amarillo. Los resultados muestran que los contenidos de pigmentos variaron estacionalmente con respecto a las especies de algas, y a los cambios de los parámetros físico-químicos, mientras que el pH, oxígeno disuelto, $\mathrm{NO}_{3}, \mathrm{NO}_{2}, \mathrm{NH}_{4}{ }^{+}$, nitrógeno total (TN) y fósfato total (TP) tuvieron un impacto directo sobre el contenido de pigmentos fotosintéticos, y la temperatura tuvo una correlación negativa significativa sobre los pigmentos fotosintéticos.
\end{abstract}

Palabras clave: Parámetros ambientales, clorofila, ficobiliproteínas, algas rojas, variación estacional

Abstract.- Seasonal changes of pigment composition [Chlorophyll a (Chl-a), total carotenoid (Car.), phycobiliproteins (phycoerythrin $(\mathrm{PE})$, phycocyanin (PC), allophycocyanin (APC))], in the 5 species of Rhodophyta were investigated. Chl-a, carotenoids and phycobiliproteins levels showed high contents during winter, whereas decreased in summer showing discoloration tissue from deep red to green or yellow. The results show that the pigment contents were varied seasonally with respect to the algal species and physical and chemical parameters changes, while $\mathrm{pH}$, dissolved oxygen, $\mathrm{NO}_{3}, \mathrm{NO}_{2} ; \mathrm{NH}_{4}^{+}$, total nitrogen (TN) and total phosphorus (TP) had direct impact on photosynthetic pigments content, and temperature had significant negative correlation on photosynthetic pigments.

Key words: Environmental parameters, chlorophyll, phycobiliproteins, red seaweeds, seasonal variation

\section{INTRODUCTION}

There is a highly diversity in the structure and pigment composition of red algae (Grossman et al. 1995, Guan et al. 2007). The quantity of macroalgal pigments is mostly used to define algal biomass. There are three different groups of light harvesting and photoprotective pigments in macroalgae, i.e., the chlorophylls, carotenoids and phycobiliproteins (Rowan 1989, Jeffrey et al. 2005). Chlorophylls are greenish pigments which contain a porphyrin ring around which electrons are free to migrate because the electrons transfer freely, the porphyrin ring has the potential to gain or lose electrons easily, and thus the potential to provide energized electrons to other molecules. This is the fundamental process by which chlorophyll captures the energy of sun light. On the other hand, carotenoids are usually red, orange, or yellow pigments, don't dissolve in water and must be attached to membranes within the cell. Carotenoids cannot transfer sunlight energy directly to the photosynthetic pathway, but pass their absorbed energy from one chlorophyll molecule to another. For this reason, they are called accessory pigments.
Phycobiliproteins are the major photosynthetic accessory pigments in cyanobacteria (blue-green algae, prokaryotic); Rhodophytes (red algae, eukaryotic); cryptomonads (biflagellate unicellular eukaryotic algae) and cyanelles (endosymbiotic plastid-like organelles). Phycobiliproteins, a group of watersoluble, brightly colored proteins characteristic for red macroalgae (Rowan 1989, Zhao et al. 2011), they are structured with an internal core of allophycocyanin (APC), several intermediate packets of phycocyanin (PC), and an external layer of phycoerythrin (PE) (Talarico 1996) that participate in an extremely efficient energy transfer chain in the reaction centers of PSII (Róman et al. 2002), and responsible for about 50\% of light capturing in cyanobacteria and red algae (Williams et al. 1980).

Phycobiliproteins can be divided broadly into 3 classes based on their spectral properties: PE (deep red) $(\lambda \max \sim 565$ $\mathrm{nm}), \mathrm{PC}$ (deep blue) $(\lambda \max \sim 620 \mathrm{~nm}$ ) and APC (bluish green) $(\lambda \max \sim 650 \mathrm{~nm})$ and a fourth phycobiliprotein known as APC 
B ( $\lambda$ max $\sim 670 \mathrm{~nm})$ (Glazer \& Bryant 1975). Light absorbed by PE is efficiently transferred to PC, then to APC and ultimately to chlorophyll (French \& Young 1952, Kronick 1986).

Phycoerythrins are the most abundant phycobiliproteins in many red algae and in some unicellular cyanobacteria. Phycoerythrin is associated with chlorophyll in Rhodophyta, and enables them to be photosynthetically efficient in deep water where blue light predominates. The longer wave length red portion of the spectrum that activate green chlorophyll pigments do not penetrate the deeper water of the photic zone, so green algae cannot survive at depth where red algae thrive.

Phycobiliproteins have gained considerable importance in the commercial sector, as they have several applications. The primary potential of these molecules are as natural dyes but a number of investigations have shown their health-promoting properties and broad range of pharmaceutical applications. Phycoerythrin is the most widely used phycobiliproteins in fluorescent probes, pharmaceutical, food industries, immunology, cell biology, flow cytometry, food, and cosmetics colorant (Glazer 1994, Sekar \& Chandramohan 2008) and has quantum yields of $82-98 \%$ (Oi et al. 1982). A number of multinational companies have commercialized antibodies conjugated with PE. C-phycocyanin (C-PC) is used in cosmetics, diagnostics and foods and as anutraceutical or biopharmaceutical (antioxidant, antimutagenic, antiviral, anticancer and immune activation, among others) (Sørensen $e t$ al. 2013, López-Cristoffanini et al. 2015).
Hence, the present study was focused on determination the variation in the pigment contents of 5 species of red seaweeds and their relation to the changes in physical and chemical parameters to determine the most suitable species and season for pigment production.

\section{MATERIALS AND METHODS}

\section{Collection of SEAWEeds}

Five species of marine Rhodophyta were hand-picked seasonally (Viz. February 2014 to January 2015) from Rocky Bay of Abu Qir (longitudes $30^{\circ} 03^{\prime}$ to $30^{\circ} 22^{\prime} \mathrm{E}$ and latitudes $31^{\circ} 16^{\prime}$ to $31^{\circ} 28 \mathrm{~N}$ ) (Fig. 1). The samples were brought to the laboratory in plastic bags containing seawater to prevent evaporation. Algae were then cleaned from epiphytes and sand particles and given a quick fresh water to remove surface salts. After washing, some of fresh samples were processed as herbarium specimens on the same day of collection; others were preserved in $5 \%$ formalin in seawater for taxonomic classification. The collected species were identified as presented in the literature, checked for synonyms and latest accepted names, referred to its systematic groups and described following the methods of Abbott \& Hollenberg (1976), Taylor (1960) \& Aleem (1993), and confirmed using AlgaeBase website (Guiry \& Guiry 2016).

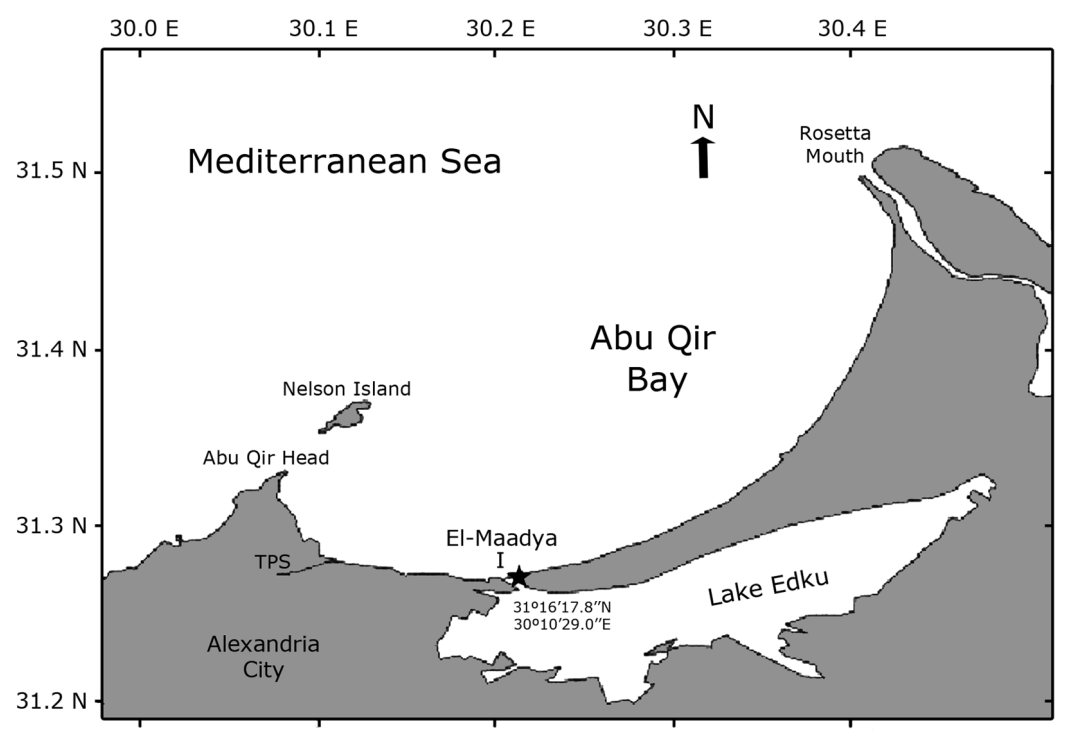

Figure 1. Location of collected samples / Ubicación de las muestras recolectadas 


\section{ENVIRONMENTAL PARAMETERS}

Water temperature $\left({ }^{\circ} \mathrm{C}\right)$, salinity (PSU), dissolved oxygen $(\mathrm{mg}$ $\mathrm{L}^{-1}$ ) and $\mathrm{pH}$ were measured with Hydrolab (Data Sonde 5X). Water samples were collected, filtered (Whatman GF/C), and analyzed for nutrients $\left(\mathrm{NO}_{2}^{-}, \mathrm{NO}_{3}^{-}, \mathrm{NH}_{4}^{+}, \mathrm{TN}\right.$ (total nitrogen) and TP (total phosphorus). The nutrient salts were determined by colorimetry according to the methods of Grasshoff (1976) using a UV-Visible spectrophotometer (Shimadzu double beam Model 150-02).

\section{Pigment analysis}

On the day of collection analysis of chlorophyll was extracted in $90 \%$ acetone and estimated by spectrophotometry according to the method of Jeffery \& Humphery (1975). The level of Chl$a$ and total chlorophyll was calculated using the following formula:

$$
\begin{aligned}
& \text { Chlorophyll } a=\frac{\left[12.7\left(\mathrm{~A}_{663}\right)-2.69\left(\mathrm{~A}_{645}\right)\right] \mathrm{x} \text { vol. of extraction }}{\text { Weight of the sample }} \mathrm{mg} \mathrm{g}^{-1} \\
& \text { Total chlorophyll }=\frac{\left[20.2\left(\mathrm{~A}_{645}\right)+8.02\left(\mathrm{~A}_{663}\right)\right] \mathrm{x} \text { vol. of extraction }}{\text { Weight of the sample }} \mathrm{mg} \mathrm{g}^{-1}
\end{aligned}
$$

where: $\mathrm{A}_{663}=$ absorbance at $663 \mathrm{~nm}, \mathrm{~A}_{645}=$ absorbance at 645 $\mathrm{nm}$ and Carotenoids were extracted in $90 \%$ acetone and estimated by the method of Ridley (1977). The level of carotenoids was estimated using the following formula and it is expressed as mg of carotenoids present in $1 \mathrm{~g}$ of fresh tissue.

$$
\text { Carotenoids }=\frac{4 \mathrm{x} \mathrm{A}_{480} \times \text { vol. of extraction }}{\text { Weight of the sample }} \mathrm{mg} \mathrm{g}^{-1}
$$

where: $\mathrm{A}_{480}=$ absorbance at $480 \mathrm{~nm}$, and $4=$ correction factor

Phycobiliproteins (PC, APC, PE) were extracted with phosphate buffer $(0.1 \mathrm{M})$ and estimated by the method of Padgett \& Krogman (1987) and calculated ( $\mathrm{mg} \mathrm{g}^{-1}$ fresh weight) using the formula:

$$
\begin{gathered}
\mathrm{PC}=\frac{\left(\mathrm{A}_{615}\right) \times\left(0.475 \times \mathrm{A}_{652}\right)}{5.34} \\
\mathrm{APC}=\frac{\left(\mathrm{A}_{652}\right)-\left(0.208 \times \mathrm{A}_{615}\right)}{5.09} \\
\mathrm{PE}=\frac{\left(\mathrm{A}_{562}\right)-(2.41 \times \mathrm{PC})-(0.849 \times \mathrm{APC})}{9.62}
\end{gathered}
$$

where: $\mathrm{A}_{562}=$ absorbance at $562, \mathrm{~A}_{615}=$ absorbance at $615 \mathrm{~nm}$ and $\mathrm{A}_{652}=$ absorbance at $652 \mathrm{~nm}$.

\section{Statistical analysis}

All reported results are the means with standard deviation $( \pm \mathrm{SD})$ of the 3 replicates. One-way analysis of variance (ANOVA) were carried out using the SPSS for Windows V15 computer statistics program to evaluate significant differences between photosynthetic pigments of some red seaweeds and different seasons.

\section{Results}

TAXONOMIC DESCRIPTION OF THE TESTED RED SEAWEEDS

The five species of Rhodophyta collected from Abu Qir Bay were identified as: Corallina elongata Ellis et Solander, Corallina officinalis Linnaeus, Jania rubens (Linnaeus) Lamouroux, Polysiphonia elongata (Hudson) Sprenge and Pterocladia capillacea (S.G. Gmelin) Bornet et Thuret.

\section{TAXONOMIC POSITION}

Phylum: Rhodophyta, Class: Florideophyceae,

Order: (1) Corallinales, Family: Corallinaceae,

(1) Corallina elongata Ellis et Solander (Fig. 2a)

Synonyms: Corallina mediterranea J.E. Areschoug.

Habitat: Epilithic on bed rock in shallow water.

Abundance and season: Dense in all seasons except in summer as compared with other collected species.

Description: Thalli up to 7-10 $\mathrm{cm}$ high, colour purple- redpink, erect, cylindrical, calcified and pinnately dichotomous branch. The stem appears segmented with segments ovoid or triangular.

Remark: Colour of specimen varied from violet grey to white ivory according to season. This species associated with Jania rubens and polychaetes.

(2) Corallina officinalis Linnaeus (Fig. 2b)

Habitat: Epilithic on bed rock and epiphytic on gastropod shell in shallow water.

Abundance and season: Dense in all seasons.

Description: Thalli up to $10-12 \mathrm{~cm}$ high, pink to red, axis cylindrical, erect and dichotomously branched, pinnate, calcareous, lateral branches $2-5 \mathrm{~cm}$ and jointed with bone like, branches bear opposite branchlets and the stem appears segmented.

Remark: This species differs from C. elongata in the lateral branching not immediately from base. Colour of dried specimen varied from violet grey to white. This species associated with Ulva fasciata, Jania rubens and polychaets. 


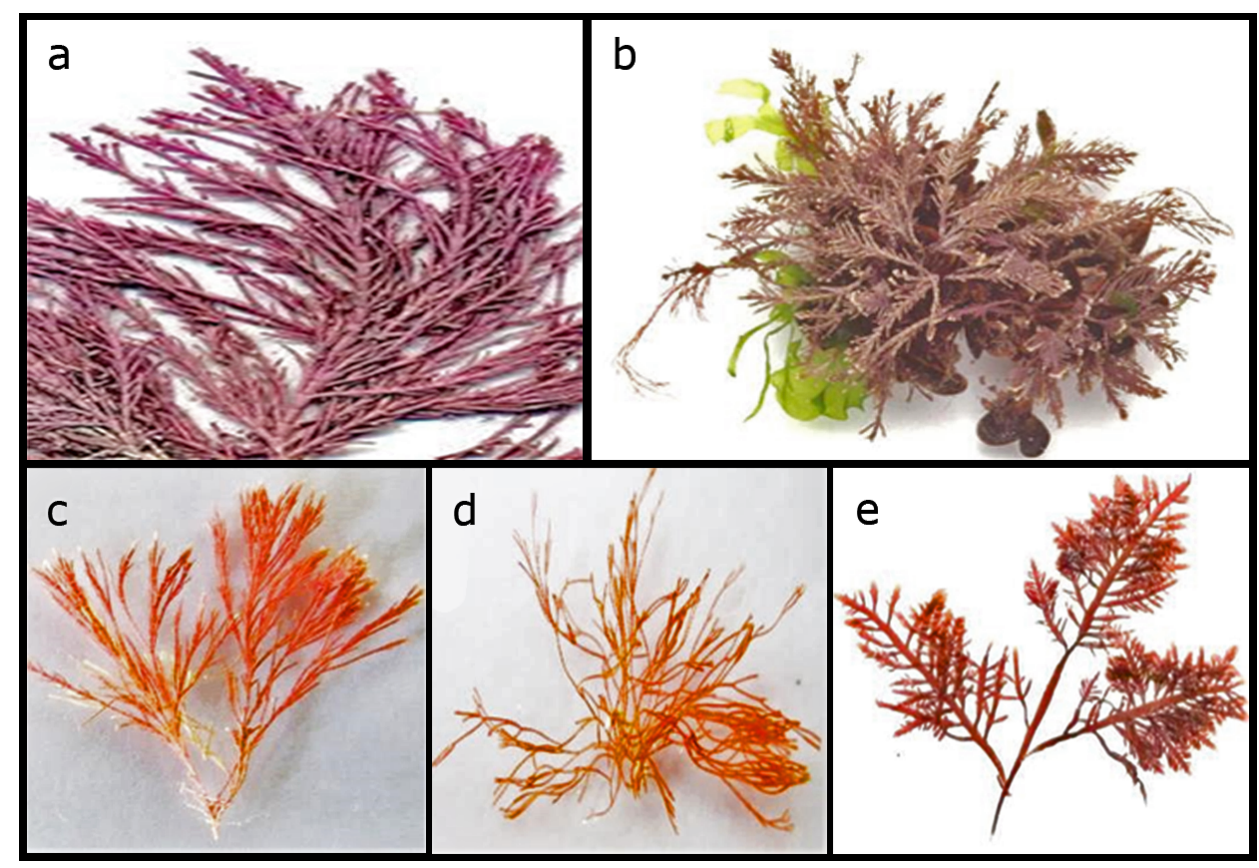

Figure 2. The fronds of five species of Rhodophyta collected from Abu Qir Bay. a) Corallina elongata, b) Corallina officinalis, c) Jania rubens, d) Polysiphonia elongata, e) Pterocladia capillacea / Frondas de las cinco especies de Rhodophyta colectadas en la bahía de Abu Qir. a) Corallina elongata, b) Corallina officinalis, c) Jania rubens, d) Polysiphonia elongata, e) Pterocladia capillacea

\section{(3) Jania rubens (Linnaeus) Lamouroux (Fig. 2c)}

Synonyms: Corallina rubens Linnaeus, Jania corniculata (Linnaeus) J.V. Lamouroux, J. spermophorus J.V. Lamouroux, C. cristata Linnaeus, C. spermophoros Linnaeus

Habitat: Epilithic on bed rock in shallow water and epiphytic on stipe of Sargassum sp.

Abundance and season: Moderate in all seasons.

Description: Thalli 2-4 cm high, pinkish red in colour, calcified clusters, segments and branching repeatedly dichotomously branched and not opposite.

Remark: This species growing attached to $C$. officinalis and C. elongata.

Order (2): Ceramiales, Family: Rhodomelaceae,

(4) Polysiphonia elongata (Hudson) Sprenge (Fig. 2d).

Synonyms: Conferva elongata Huds.

Habitat: Epilithic on rock grow near the water level down to a depth of $1 \mathrm{~m}$.

Abundance and season: Moderate in all seasons.
Description: Thalli up to $4 \mathrm{~cm}$, brownish to purplish red in colour, dense bushes on the substratum, cartilaginous, cylindrical, branches alternate topseudo dichotomous, heterotrichous form, a central axial cell with 4 periaxial.

Order (3): Gelidiales, Family: Gelidiaceae,

\section{(5) Pterocladia capillacea (S. G. Gmelin) Bornet et Thuret (Fig. 2e).}

Synonyms: Gelidium capillaceum (S.G. Gmel.) Kütz., Pterocladia pinnata (Hudson.) Papenfuss, Fucus capillaceus S.G. Gmel. (Basionym), Gelidium capillaceum (S.G. Gmel.) Kutz.

Habitat: Epilithic on bed rock grow near the water level down to a depth of $1 \mathrm{~m}$.

Abundance and season: Moderate in all seasons.

Description: Thalli up to 5-7 cm high, consisting of erect and prostrate dark red axes. Branches alternate on the main axis and the lateral branches reached to $0.5-1.5 \mathrm{~cm}$ tall

Remark: It is associated with Ulva compressa. 


\section{ENVIRONMENTAL PARAMETERS AND PIGMENT CONTENTS}

The environmental parameters such as temperature, salinity, $\mathrm{pH}$, dissolved oxygen and nutrient content (e.g., $\mathrm{NO}_{3}{ }^{-}, \mathrm{NO}_{2}{ }^{-}, \mathrm{NH}_{4}^{+}$ TN and TP) were measured from February 2014 to January 2015 and are presented in Table 1 and 2. All of the measured environmental parameters varied significantly throughout the year. The minimum and maximum temperature values were $18^{\circ} \mathrm{C}$ during winter and $29^{\circ} \mathrm{C}$ during summer. Salinity was increased gradually after spring owing to evaporation and atmospheric heating. The minimum value was recorded during winter (35.5 PSU) whereas, the maximum during autumn (37.01 PSU). The highest values of water dissolved oxygen were recorded during winter (10.58 $\left.\mathrm{mg} \mathrm{L}^{-1}\right)$, whereas the lowest during autumn (2.65 $\left.\mathrm{mg} \mathrm{L}^{-1}\right)$.

The concentration of nutrients showed significant variation throughout the study. The concentration of $\mathrm{NO}_{3}{ }^{-}$and $\mathrm{NO}_{2}{ }^{-}$ varied from 11.58 and $1.97 \mu \mathrm{M}$ in winter to 2.56 and $1.22 \mu \mathrm{M}$ in summer, respectively. From a seasonal perspective, the $\mathrm{NH}_{4}^{+}$ concentration showed lower values $(3.82 \mu \mathrm{M})$ in the winter and higher values in spring $(15.21 \mu \mathrm{M})$. The maximum concentration of TP was recorded in autumn $(9.87 \mu \mathrm{M})$ and the minimum in spring $(22.1 \mu \mathrm{M})$.

Table 1. Effect of some physical parameter on red seaweeds algae distribution / Efecto de algunos parámetros físicos sobre la distribución de algas rojas

\begin{tabular}{|c|c|c|c|c|c|c|}
\hline Season & Scientific name & Abundance & $\begin{array}{c}\text { Temperature } \\
\left({ }^{\circ} \mathrm{C}\right)\end{array}$ & Salinity & $\mathrm{pH}$ & $\begin{array}{c}\text { DO } \\
\left(\mathrm{mg} \mathrm{L}^{-1}\right)\end{array}$ \\
\hline \multirow{5}{*}{ 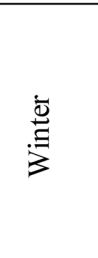 } & Corallina elongata & $* * *$ & \multirow{5}{*}{$18 \pm 0.5$} & \multirow{5}{*}{$35.52 \pm 0.4$} & \multirow{5}{*}{$8.84 \pm 0.2$} & \multirow{5}{*}{10.58} \\
\hline & Corallina officinalis & $* * *$ & & & & \\
\hline & Jania rubens & $* *$ & & & & \\
\hline & Pterocladia capillacea & $* *$ & & & & \\
\hline & Polysiphonia elongata & $* *$ & & & & \\
\hline \multirow{5}{*}{$\stackrel{\infty}{\stackrel{\infty}{\Xi}}$} & Corallina elongata & $* * *$ & \multirow{5}{*}{$24 \pm 1.0$} & \multirow{5}{*}{$36.59 \pm 0.5$} & \multirow{5}{*}{$8.57 \pm 0.2$} & \multirow{5}{*}{10.4} \\
\hline & Corallina officinalis & $* * *$ & & & & \\
\hline & Jania rubens & $* *$ & & & & \\
\hline & Pterocladia capillacea & $* *$ & & & & \\
\hline & Polysiphonia elongata & $* *$ & & & & \\
\hline \multirow{5}{*}{$\begin{array}{l}\dot{\bar{\Xi}} \\
\stackrel{\Xi}{\Xi} \\
\ddot{\Xi}\end{array}$} & Corallina elongata & $*$ & \multirow{5}{*}{$29 \pm 0.5$} & \multirow{5}{*}{$36.77 \pm 0.3$} & \multirow{5}{*}{$8.45 \pm 0.1$} & \multirow{5}{*}{4.74} \\
\hline & Corallina officinalis & $* * *$ & & & & \\
\hline & Jania rubens & $* *$ & & & & \\
\hline & Pterocladia capillacea & $* *$ & & & & \\
\hline & Polysiphonia elongata & $* *$ & & & & \\
\hline \multirow{5}{*}{$\underset{\Xi}{\Xi}$} & Corallina elongata & $* * *$ & \multirow{5}{*}{$21.5 \pm 1.5$} & \multirow{5}{*}{$37.01 \pm 0.1$} & \multirow{5}{*}{$8.22 \pm 0.1$} & \multirow{5}{*}{2.65} \\
\hline & Corallina officinalis & $* * *$ & & & & \\
\hline & Jania rubens & $* *$ & & & & \\
\hline & Pterocladia capillacea & $* *$ & & & & \\
\hline & Polysiphonia elongata & $* *$ & & & & \\
\hline & $\mathrm{F}$ & & $68.467 * *$ & $10.534 *$ & $7.992 *$ & $196.16^{* *}$ \\
\hline & $P$ & & $<0.001$ & $<0.001$ & $<0.001$ & $<0.001$ \\
\hline
\end{tabular}

Note: $* * *=$ dense, $* *=$ moderate, $*=$ rare. Values represent mean values \pm standard deviation $(\mathrm{n}=3) . *$ Significant $P<0.05$, ** highly significant $P<0.01, * * *$ highly significant $P<0.001$ 
Table 2. Seasonal average concentrations of $\mathrm{NO}_{3} ; \mathrm{NO}_{2} ; \mathrm{NH}_{4}^{+}$, total nitrogen (TN) and total phosphate (TP) $(\mu \mathrm{M})$ in water of Abu Qir Bay / Concentraciones promedio estacionales de $\mathrm{NO}_{3}, \mathrm{NO}_{2}, \mathrm{NH}_{4}{ }^{+}$, nitrógeno total (TN) y fosfato total (TP) $(\mu \mathrm{M})$ en aguas de la bahía Abu Qir

\begin{tabular}{cccccc}
\hline Season & \multicolumn{1}{c}{$\mathrm{NO}_{3}$} & \multicolumn{1}{c}{$\mathrm{NO}_{2}$} & \multicolumn{1}{c}{$\mathrm{NH}_{4}$} & $\mathrm{TN}$ & \multicolumn{1}{c}{$\mathrm{TP}$} \\
\hline Winter & $11.58 \pm 5.62$ & $1.97 \pm 0.96$ & $3.82 \pm 1.05$ & $302.27 \pm 4.12$ & $5.98 \pm 0.39$ \\
Spring & $2.77 \pm 1.10$ & $1.22 \pm 0.22$ & $15.21 \pm 2.51$ & $337.2 \pm 3.54$ & $2.51 \pm 0.23$ \\
Summer & $2.56 \pm 0.86$ & $1.12 \pm 0.23$ & $8.99 \pm 2.83$ & $290.17 \pm 6.45$ & $2.62 \pm 0.74$ \\
Autumn & $10.96 \pm 10.8$ & $1.89 \pm 0.98$ & $8.77 \pm 2.56$ & $337.72 \pm 5.15$ & $9.87 \pm 0.54$ \\
$\mathrm{~F}$ & $17.836^{* *}$ & $1.181^{*}$ & $11.890^{* *}$ & $72.685^{* *}$ & $139.06^{* *}$ \\
$P$ & $<0.001$ & $<0.001$ & $<0.001$ & $<0.001$ & $<0.001$ \\
\hline
\end{tabular}

Values represent mean values \pm standard deviation $(\mathrm{n}=3)$

* Significant $P<0.05, * *$ highly significant $P<0.01$,*** highly significant $P<0.001$

Five species of red algae, Corallina elongata Ellis et Solander, C. officinalis Linnaeus, Jania rubens (Linnaeus) Lamouroux, Polysiphonia elongata (Hudson) Sprenge and Pterocladia capillacea (S.G. Gmelin) Bornet et Thuret were analyzed for photosynthetic pigments, Chl- $a$, Car., PE, PC and APC production during different seasons (Figs. 3 and 4).

The chlorophyll $a$ concentration in the tested red algae exhibited significant changes in relation to species and environmental factors at different seasons. Chlorophyll $a$ content of the tested seaweeds showed maximum and minimum values in the winter and summer, respectively. Polysiphonia elongata showed higher percentage of Chl- $a$ in all seasons ranged from $2.55 \mathrm{mg} \mathrm{g}^{-1} \mathrm{FW}$ in summer to $3.847 \mathrm{mg} \mathrm{g}^{-1} \mathrm{FW}$ in winter, while the minimum value was recorded in C. elongata $\left(0.49 \mathrm{mg} \mathrm{g}^{-1}\right.$ $\mathrm{FW}$ ) and $J$. rubens $\left(0.55 \mathrm{mg} \mathrm{g}^{-1} \mathrm{FW}\right)$ in summer.

The pigment content of the tested seaweeds showed maximum and minimum values in the winter and summer, respectively. Polysiphonia elongata showed higher percentage of total chlorophyll in all seasons ranged from $3.82 \mathrm{mg} \mathrm{g}^{-1} \mathrm{FW}$ in summer to $5.63 \mathrm{mg} \mathrm{g}^{-1} \mathrm{FW}$ in winter, while the minimum value was recorded in $J$. rubens $\left(2.73 \mathrm{mg} \mathrm{g}^{-1} \mathrm{FW}\right)$ in winter; C. elongata $\left(1.75 \& 1.55 \mathrm{mg} \mathrm{g}^{-1} \mathrm{FW}\right)$ in spring and autumn season, respectively and $C$. officinalis in summer $\left(1.69 \mathrm{mg} \mathrm{g}^{-1}\right.$ FW).

Carotenoid also showed a similar pattern as total chlorophyll in the tested seaweeds. P. elongata exhibited higher content of $0.609 \mathrm{mg} \mathrm{g}^{-1} \mathrm{FW}$, whereas the lower content $\left(0.28 \mathrm{mg} \mathrm{g}^{-1} \mathrm{FW}\right)$ was recorded in J. rubens in winter seasons (Fig. 3).

The variations in the phycobiliproteins content in the tested seaweeds are shown in Fig. 4. During the study period, there were significant differences in PE content in the tested seaweeds
Table 3. The seasonal changes in carotenoid/ Chl a ratio in collected seaweeds / Cambios estacionales en la relación carotenoides/ $\mathrm{Chl}$ a en las macroalgas recolectadas

\begin{tabular}{lcccc}
\hline \multirow{2}{*}{\multicolumn{1}{c}{ Species }} & \multicolumn{4}{c}{ Car./ Chl- $a$} \\
\cline { 2 - 5 } & Winter & Spring & Summer & Autumn \\
\hline Corallina elongata & 0.298 & 0.455 & 0.358 & 0.406 \\
Corallina officinalis & 0.117 & 0.126 & 0.126 & 0.223 \\
Jania rubens & 0.273 & 0.102 & 0.373 & 0.287 \\
Pterocladia capillacea & 0.327 & 0.370 & 0.426 & 0.459 \\
Polysiphonia elongata & 0.158 & 0.166 & 0.031 & 0.065 \\
\multicolumn{1}{c}{ F } & $6.655^{*}$ & $20.002^{* *}$ & $17.929^{* *}$ & $73.359^{* * *}$ \\
$P$ & $<0.001$ & $<0.001$ & $<0.001$ & $<0.001$ \\
\hline
\end{tabular}

Values represent mean values \pm standard deviation $(\mathrm{n}=3)$

* Significant $P<0.05$, ** highly significant $P<0.01$,*** highly significant $P<0.001$

according to the different seasons. P. elongata showed highest concentration of PC, APC and PE $(2.38,6.23$ and $3.70 \mathrm{mg}$ $\mathrm{g}^{-1} \mathrm{FW}$, respectively), whereas $J$. rubens recorded lowest content of them $\left(0.51,2.05\right.$ and $\left.0.91 \mathrm{mg} \mathrm{g}^{-1} \mathrm{FW}\right)$ in winter season.

The ratios of Car/Chl $a$ pigment of different seaweeds are shown in Table 3. Changes in Car/Chl $a$ ratio of all tested seaweeds during four seasons showed highly significant different between species and seasons. The highest $\mathrm{Car} / \mathrm{Chl} a$ ratio was noted in Pt. capillacea (0.46) in autumn and the lowest ratio was recorded in P. elongata (0.03) during summer season.

\section{Discussion}

In the present investigation, an attempt has been made to determine the changes in photosynthetic pigments (Chl- $a$, carotenoid and phycobiliproteins (EC, PE and APC)) in most common red seaweeds in Abu Qir Bay, Mediterranean Sea in 

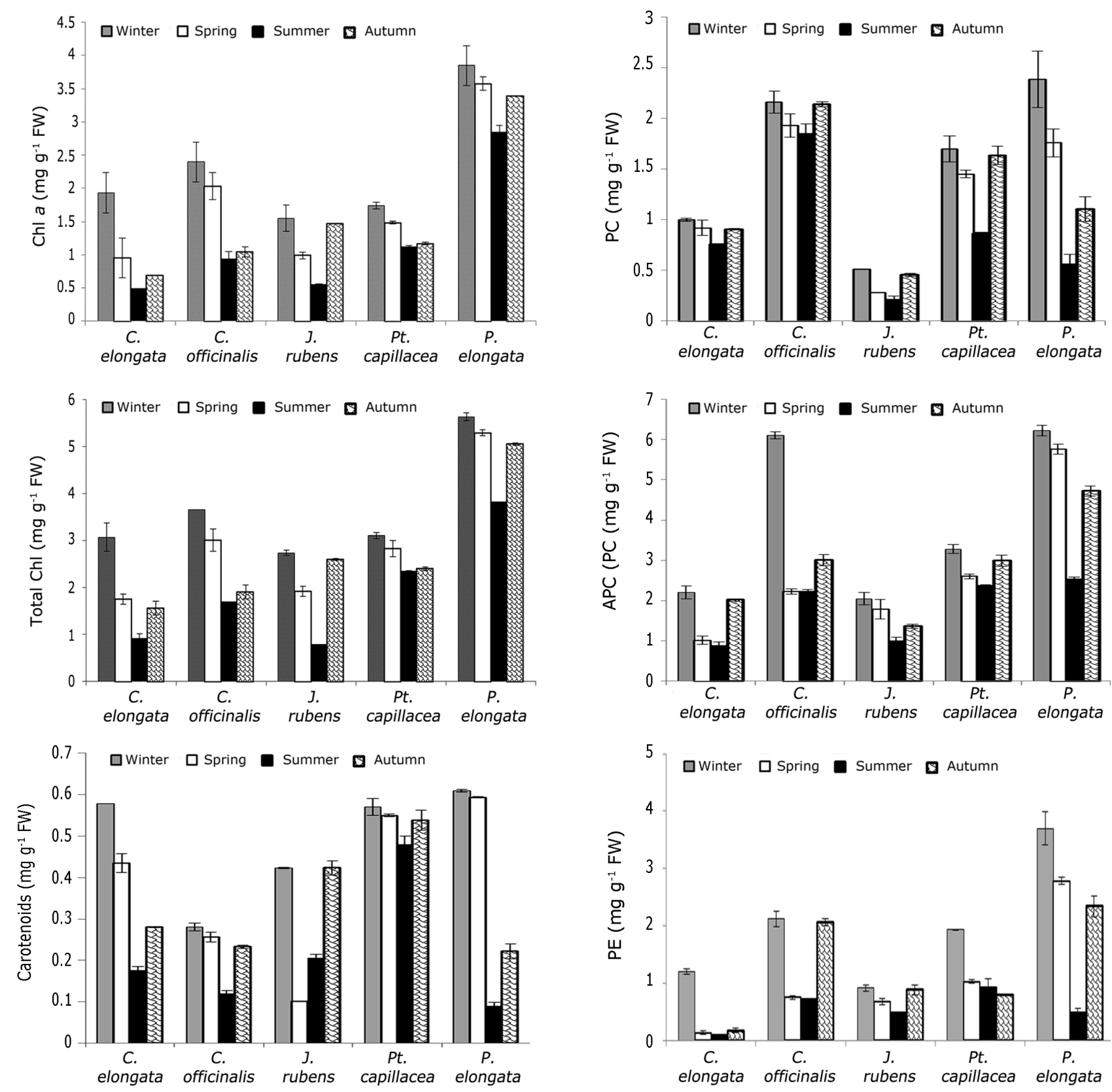

Figure 3. Seasonal variation in chlorophylls and carotenoids content of the common red seaweeds / Variación estacional en el contenido de clorofila y carotenoides de macroalgas rojas comunes

Figure 4. Seasonal variation in phycobiliproteins (PC, APC, PE) content of the common red seaweeds / Variación estacional en el contenido de ficobiliproteínas (PC, APC, PE) de macroalgas rojas comunes 
response to species, season and environmental parameters (temperature, $\mathrm{pH}$, salinity, dissolved oxygen, $\mathrm{NO}_{3}^{-}, \mathrm{NO}_{2}^{-}, \mathrm{NH}_{4}^{+}$, TN and TP). Our results are similar to those described by Neish et al. (1977) who stated that red algae show a characteristic summer discoloration which is regarded as a loss of pigment related to environmental conditions. Schreiber (1979) reported that the phycobilins content vary seasonally in different seaweeds. Paerl (1984) and Rowan (1989) reported that the concentration and distribution of photoprotective plant pigments vary with season in micro- and macroalgae and with tissue type in macroalgal species.

The present data showed that environmental factors especially $\mathrm{pH}$, dissolved oxygen, $\mathrm{NO}_{3}^{-}, \mathrm{NO}_{2}^{-}, \mathrm{NH}_{4}^{+}$, $\mathrm{TN}$ and TP had positive correlation effect on photosynthetic pigment contents, while seaweeds are efficient in the uptake of nitrate, ammonium, and phosphate from seawater, and the assimilation of these nutrients into nitrogenous compounds (e.g. amino acids, proteins, pigments) (Lobban \& Harrison 1997). The results showed that all estimated photosynthetic pigments were at the maximum level in winter when the level of the nutrient is at the highest value. On the other hand, the levels of photosynthetic pigments began to decrease in the spring and reached to minimum value in summer then increased again in autumn correlated to the value of these nutrients.

Our results are in line to those described by other authors, who reported an increase in total soluble proteins and phycobiliproteins in winter and a drop in summer (Kosovel \& Talarico 1979, Campbell et al. 1999, Aguilera et al. 2002, Orduña-Rojas et al. 2002). The environmental variation in light, temperature, desiccation and nutrients can influence and bring about changes in the concentration of pigments in the thallus (Ramus et al. 1976, Contreras-Porcia et al. 2011). Mizuta (2002) found that Chl- $a$ and PE levels of Gloiopeltis furcate and Porphyra yezoensis were high during winter, but decreased in late spring or summer. Dere et al. (2003) stated that the pigment content may increase in response to the environmental factors such as high nutrient availability. Both PE and PC concentrations showed clear trends of decreasing concentration with increasing temperature (Latham 2008). Pereira et al. (2012) stated that the concentration of R-Phycoerythrin (RPE) and Chl- $a$ in Gracilaria bursapastor is showed maximum values in the winter and minimum values in summer.

The obtained results in this study show that the increase in all photosynthetic pigment may be correlated with nitrogen and phosphorus of seawater due to the vital role of these nutrients in algal metabolic process, while the nutrients nitrate $(\mathrm{N})$ and phosphate $(\mathrm{P})$ are two of the most important elements required for algal growth and metabolism (DeBoer 1981, Lapointe 1987). Nitrogen amount also changes algal pigment composition, particularly the level of PE (Lapointe 1981, Bird et al. 1982, Lapointe 1985), where phycobiliprotein synthesis depends on the supply of nitrogen in the environment (Liotenberg et al. 1996). This observation is similar to that observed by Kolber et al. (1988) who stated that nitrogen depletion caused reduction in chlorophyll content, oxygen evolution, carbon dioxidefixation, and tissue production. Lapointe (1981, 1985) reported that a high nitrogen environment results in an increase of PE and Chl- $a$ in G. foliifera. Amano \& Noda (1988) detected that, PE content of Porphyra yezoensis was increased five times by nitrogen enrichment. Nitrogen commonly results in an increase in $\mathrm{N}$ containing photosynthetic pigments such as chlorophyll and phycobilins (Dawes 1995, Vergara et al. 1995). Rico \& Fernández (1996) showed that nitrogen and PE in Gelidium latifolium were decreased in low ambient nitrate conditions. Nitrogen enrichment increases both Chl- $a$ and phycobilin of some Rhodophyta e.g., Gelidium latifolium (Rico \& Fernándes 1996), Chondrus crispus (Neish et al. 1977) and Porphyra yezoensis (Amano \& Noda 1987). In another report, Andria et al. (1999) demonstrated that PE contents of Gracilaria sp. (Rhodophyta) decreased when it was grown under low nitrogen availability, and indicated the role of these compounds as nitrogen storage pools under conditions of nutrient limitation and their allocation for growth. Phycoerythrin content in Gloiopeltis furcate (Postels et Ruprecht) J. Agardh, and Porphyra yezoensis Ueda correlated significantly with nitrogen content (Mizuta et al. 2002). Pereira et al. (2012) found that nitrate was assimilated as PC and PE by Porphyra dioica Brodie and Irvine and phycoerythrin PE was the main form of nitrogen pool, while, phosphorus participates in the formation of biomolecules such as nucleic acids, proteins and phospholipids. In the same year, Marinho-Soriano (2012) showed the importance of $\mathrm{NO}_{3}$ for the biosynthesis of this pigment, demonstrated the positive correlation between them.

The most important role of phosphorus is in energy transfer mediated by ATP and other high energy compounds present in photosynthesis and respiration (Lobban \& Harrison 1997). Chlorophyll a of Hypnea cervicornis (red algae) was stimulated by high phosphate (Bird et al. 1982). Lapointe (1986) detected that phosphorus enrichment can stimulate the growth and the photosynthetic rates of some algae, and Martins et al. (2011) found that there is a positive correlation between the increase of phosphate in the medium and the content of Hypnea musciformis photosynthetic pigments.

Under nitrogen and phosphate limitation, PE concentrations of G. tikvahiae showed low values because this pigment was preferentially metabolized to provide nutrients to sustain the algal growth (Bird et al. 1982). Our results are in contrast with that of Chopin et al. (1995) who found that phosphorus had no significant effect on photosynthesis and photosynthetic pigment contents in Chondrus crispus. 
Concerning the effect of temperature on photosynthetic pigments of tested seaweeds, the results showed that temperature had significant negative correlation on photosynthetic pigments. It can be concluded that the increase of photosynthetic pigments is correlated with the decrease in temperature as the maximum value of photosynthetic pigments were recorded in winter while the lowest temperature caused increase in the pigment content. Many researchers have reached the same conclusion. For example, Liu \& Dong (2001) found that PE and chlorophyll contents of G. tenuistipitata decreased if the light intensity was increased due to increase in temperature. Furthermore, Zucchi \& Necchi (2001) determined that physical factors, such as light density and quality, photoperiod and temperature can alter pigment contents of red algae. MarinhoSoriano (2012) stated that the RPE content of G. bursapastoris (Rhodophyta) was negatively correlated with temperature. Their results were in accordance with that of Vanitha \& Chandra (2012) who recorded that temperature and light intensity play a major role in the pigment production of red algae. Ding et al. (2013) stated that salinity and temperature have significant or extremely significant effects on photosynthetic pigments (Chla, Car, PE and PC) in H. cervicornis.

In conclusion, the present study demonstrated the seasonal variations in photosynthetic pigments of five red algal species and their relationships to environmental parameters and photosynthetic pigment contents. Our results show that winter season is the most suitable for production of high concentration of photosynthetic pigments of the species collected from the studied location (Abu Qir Bay, Mediterranean Sea, Alexandria).

\section{LITERATURE CITED}

Abbott IA \& IG Hollenberg. 1976. Marine algae of California, 844 pp. Stanford University Press, Stanford.

Aguilera J, K Bischof, U Karsten, D Hanelt \& C Wiencke. 2002. Seasonal variation in the ecophysiological patterns in macroalgae from an Artic fjord. II. Pigment accumulation and biochemical defence systems against high light stress. Marine Biology 140: 1087-1095.

Aleem AA. 1993. The marine algae of Alexandria. Egypt, 139 pp. Privately published, University of Alexandria, Alexandria.

Amano H \& H Noda. 1987. Effect of nitrogenous fertilizers on the recovery of discoloured fronds of Porphyra yezoensis. Botanica Marina 30: 467-473.

Andria JR, JJ Vergara \& JL Perez-Llorens. 1999. Biochemical responses and photosynthetic performance of Gracilaria sp. (Rhodophyta) from Cádiz, Spain, cultured under different inorganic carbon and nitrogen levels. European Journal of Phycology 34: 497-504.
Bird KT, C Habig \& T DeBusk. 1982. Nitrogen allocation and storage patterns in Gracilaria tikvahiae (Rhodophyta). Journal of Phycology 18: 344-348.

Campbell SJ, JS Bité \& TR Burridge 1999. Seasonal patterns in the photosynthetic capacity, tissue pigment and nutrient content of developmental stages of Undaria pinnatifida (Phaeophyta: Laminariales) in Port Phillip Bay, South Eastern Australia. Botanica Marina. 42: 231-241.

Chopin T, T Gallant \& I Davison. 1995. Phosphorus and nitrogen nutrition in Chondrus crispus (Rhodophyta): Effects on total phosphorus and nitrogen content, carrageenan production, and photosynthetic pigments and metabolism. Journal of Phycology 31: 283-293.

Contreras-Porcia L, D Thomas, V Flores \& JA Correa. 2011. Tolerance to oxidative stress induced by desiccation in Porphyra columbina (Bangiales, Rhodophyta). Journal of Experimental Botany 62: 1815-1829.

Dawes CJ. 1995. The effect of nutrient and photon fluence on the photosynthetic responses of red and pigmented cultivars of Eucheuma denticulatum. Botanica Marina 38: 323-327.

DeBoer JA. 1981. Nutrients. In: Lobban CS \& MJ Wynne (eds). The biology of seaweeds. Botanical Monograph 17:356-392. University of California Press, Berkeley/Los Angeles.

Dere S, N Dalkiran, D Karacaoðlu, G Yildiz \& E Dere. 2003. The determination of total protein, total soluble carbohydrate and pigment contents of some GemlikKaracaali (Bursa) and Erdek-Ormanli (Balikesir) in the Sea Marmara, Turkey. Oceanologia 45: 453-471.

Ding L, Y Ma, B Huang \& S Chen. 2013. Effects of seawater salinity and temperature on growth and pigment contents in Hypnea cervicornis J. Agardh (Gigartinales, Rhodophyta). BioMed Research International 2013, 10 pp. ID 594308. <http://dx.doi.org/10.1155/2013/594308>

French CS \& VK Young. 1952. The fluorescence spectra of red algae and the transfer of energy from phycoerythrin to phycocyanin to chlorophyll. Journal of General Physiology 35(6): $873-890$

Glazer AN. 1994. Phycobiliproteins-a family of valuable, widely used fluorophores. Journal of Applied Phycology 6(2): 105112 .

Glazer AN \& DA Bryant. 1975. Allo-phycocyanin B ( $\lambda \max$ $671,618 \mathrm{~mm}$ ): a new cyanobacterial phycobiliprotein. Archives of Microbiology 104: 15-22.

Grasshoff K. 1976. Methods of seawater analysis, 317 pp. Verlag Chemie, Weinheim/New York.

Grossman A, D Bhaya, K Apt \& D Kohoe. 1995. Lightharvesting complexes in oxygenic photosynthesis: diversity, control and evolution. Annual Review of Genetics 29: 231288.

Guan X, S Qin, F Zhao, X Zhang \& X Tang. 2007. Phycobilisomes linker family in cyanobacterial genomes: divergence and evolution. International Journal of Biological Sciences 3: 434-455. 
Guiry MD \& GM Guiry. 2016. AlgaeBase. World-wide electronic publication, National University of Ireland, Galway. <http://www.algaebase.org>

Jeffrey SW \& GF Humphrey. 1975. New spectrophotometric equations for determining chlorophylls $\mathrm{a}, \mathrm{b}, \mathrm{c}_{1}$ and $\mathrm{c}_{2}$ in higher plants, algae and natural populations. Biochemie und Physiologie der Pflanzen 167: 191-194.

Jeffrey S, S Wright \& R Mantoura. 2005. Phytoplankton pigments in oceanography: guidelines to modern methods, 661 pp. UNESCO, Paris.

Kolber Z, J Zehr \& PG Falkowski. 1988. Effects of growth irradiance and nitrogen limitation on photosynthetic energy conversion in photosystem II. Plant Physiology 88: 923-929.

Kosovel V \& L Talarico. 1979. Seasonal variation of phorosynthetic pigments in Gracilaria verrucose (Huds.) Papenfuss (Florideophyceae-Gigartinales). Bolletino della Societa Adriatica di Scienze 63: 5-15.

Kronick MN. 1986. The use of phycobiliproteins as fluorescent labels in immunoassay. Journal of Immunology Methods 92(1): 1-13.

Lapointe BE. 1981. The effects of light and nitrogen on growth, pigment content, and biochemical composition of Gracilaria foliifera $v$. angustissima (Gigartinales, Rhodophyta). Journal of Phycology 17: 90-95.

Lapointe BE. 1985. Strategies for pulsed nutrients supply to Gracilaria cultures in the Florida keys: Interactions between concentration and frequency of nutrient pulses. Journal of Experimental Marine Biology Ecology 93: 211-222.

Lapointe BE. 1987. Phosphorus-limited photosynthesis and growth of Sargassum natans and Sargassum fluitans (Phaeophyceae) in the Western North Atlantic. Deep Sea Research 33: 391-399.

Latham H. 2008. Temperature stress-induced bleaching of the coralline alga Corallina officinalis: a role for the enzyme bromoperoxidase. Bioscience Horizons 1(2): 105-113.

Liotenberg S, D Campbell, R Rippka, J Houmard \& N Tandeau de Marsac. 1996. Effect of the nitrogen source on phycobiliprotein synthesis and cell reserves in a chromatically adapting filamentous cyanobacterium. Microbiology 142: 611-622.

Liu JW \& SL Dong. 2001. Interactions between light and temperature on the growth and levels of chemical constituents of Gracilaria tenuistipitata var. Liui. Journal of Ocean, University of Qingdao 31(3): 332-338.

Lobban CS \& P Harrison. 1994. Seaweed ecology and physiology, 366 pp. Cambridge University Press, Cambridge.

López-Cristoffanini C, J Zapata, F Gaillard, P Potin, JA Correa \& L Contreras-Porcia. 2015. Identification of proteins involved in desiccation tolerance in the red seaweed Pyropia orbicularis (Rhodophyta, Bangiales). Proteomics 15:3954-3968.
Marinho-Soriano A. 2012. Effect of depth on growth and pigment contents of the macroalgae Gracilaria bursapastoris. Brazilian Journal of Pharmaceutical 22(4): 730-735.

Martins AP, OP Junior, P Colepicolo \& NS Yokoya. 2011. Effects of nitrate and phosphate availabilities on growth, photosynthesis and pigment and protein contents in colour strains of Hypnea musciformis (Wulfen in Jacqu.) J.V. Lamour. (Gigartinales, Rhodophyta). Brazilian Journal of Pharmaceutical 21(2): 340-348.

Mizuta H, Y Shirakura \& H Yasui. 2002. Relationship between phycoerythrin and nitrogen content in Gloiopeltis furcata and Porphyra yezoensis. Algae 17(2): 89-93.

Neish AC, PF Shacklock CH Fox \& FJ Simpson. 1977. The cultivation of Chondrus crispus. Factors affecting growth under greenhouse conditions. Canadian Journal of Botany 55: 2263-2271.

Oi VT, AN Glazer \& L Stryer. 1982. Fluorescent phycobiliprotein conjugates for analyses of cells and molecules. The Journal of Cell Biology 93: 981-986.

Orduña-Rojas J, D Robledo \& CJ Dawes. 2002. Studies on the tropical agarophyte Gracilaria cornea J. Agardh (Rhodophyta, Gracilariales) from Yucatán, Mexico. I. Seasonal physiological and biochemical responses. Botanica Marina 45: 453-458.

Padget MP \& DW Krogman. 1987. Large scale preparation of pure phycobiliproteins. Photosynthetic Research 11: 225235.

Paerl H. 1984. Cyanobacterial carotenoids: their roles in maintaining optimal photosynthetic production among aquatic bloom forming genera. Oecologia 61: 143-149.

Pereira DC, TG Trigueiro, P Colepicolo \& E MarinhoSoriano. 2012. Seasonal changes in the pigment composition of natural population of Gracilaria domingensis (Gracilariales, Rhodophyta). Brazilian Journal of Pharmaceutical 22(4): 874-880.

Ramus J, SI Beale, A Mauzerall \& KL Howard. 1976. Change in photosynthetic pigments concentration in seaweeds as a function of water depth. Marine Biology 37: 223-229.

Rico JM \& C Fernández. 1996. Seasonal nitrogen metabolism in an intertidal population of Gelidium latifolium (Gelidiaceae, Rhodophyta). European Journal of Phycology 31:149-155.

Ridley SM. 1977. Interaction of chloroplasts with inhibitors. Induction of chlorosis by diuron during prolonged illumination in vitro. Plant Physiology 59: 724-732.

Rowan KS. 1989. Photosynthetic pigments of algae, 317 pp. Cambridge University Press, Cambridge.

Schreiber U. 1979. Cold-induced uncoupling of energy transfer between phycobilins and chlorophyll in Anacytisnidulans. FEBS Letter 107(1): 4-9. 
Sekar S \& M Chandramohan. 2008. Phycobiliproteins as a commodity: trends in applied research, patents and commercialization. Journal of Applied Phycology 20(2): 113136.

Sørensen L, A Hantke \& NT Eriksen. 2013. Purification of the photosynthetic pigment C-phycocyanin from heterotrophic Galdieria sulphuraria. Journal of Science Food and Agriculture 93(12): 2933-2938.

Taylor WR. 1960. Marine algae of tropical and subtropical Americas, pp. 870-880. University Michigan Press, Ann Arbor.

Vanitha A \& S Chandra. 2012. Studies on photosynthetic pigments of some red algae of Covelong, Chennai (India). International Journal of Current Research 149-154.

Vergara JJ, KT Bird \& FX Niell. 1995. Nitrogen assimilation following $\mathrm{NH}_{4}^{+}$pulses in the red alga Gracilariopsis lemaneiformis: effect on C metabolism. Marine Ecology Progress Series 122: 253-263.
Williams R, J Gingrich \& A Glazer. 1980. Cyanobacterial phycobilisomes particles from synechocystis 6701 and two pigment mutants. Journal of Cell Biology 85(3): 558.

Zhao K-H, RJ Porra \& H Scheer. 2011. Phycobiliproteins. In: Roy S, E Egeland, CA Lewellyn \& G Johnsen (eds). Phytoplankton pigments: Updates on characterization, chemotaxonomy and applications in oceanography, pp. 375411. Cambridge University Press, Cambridge.

Zucchi MR \& O Necchi. 2001. Effects of temperature, irradiance and photoperiod on growth and pigment content in some freshwater red algae in culture. Phycological Research 49: 103-114. 